\title{
Evaluation of commercially available talc formulations of bioagents for management of sheath blight of rice and their effect on plant growth enhancement
}

\author{
RESHU*, SATYAPRAKASH ${ }^{1}$, MAHAVIR SINGH ${ }^{1}$ AND R.K. SINGH ${ }^{2}$
}

Krishi Vigyan Kendra, BULANDSHAHR (U.P.) INDIA

${ }^{1}$ Krishi Vigyan Kendra, SAHARANPUR (U.P.) INDIA

${ }^{2}$ Krishi Vigyan Kendra, MORADABAD (U.P.) INDIA

\section{ARITCLE INFO}

Received : 31.01 .2017

Revised : 15.03 .2017

Accepted : 19.03.2017

\section{KEY WORDS :}

Rice, Biological control, Sheath blight, Rhizoctonia solani, Plant growth

\begin{abstract}
The effectiveness of commercially available talc formulations of Trichoderma harzianum and Pseudomonas fluorescens applications either alone or in combination on rice crop growth, sheath blight disease and grain yield was investigated in field experiments. Seed and soil application of T. harzianum and $P$. fluorescens resulted in significant reduction of sheath blight disease incidence caused by Rhizoctonia solani and was comparable to the treatment with a systemic fungicide carbendazim (seed and foliar application). Lowest sheath blight severity was recorded in the treatment comprising combined application of T. harzianum and P. fluorescens (9.50\%) whereas, 10.6 per cent sheath blight severity was recorded in plot receiving seed and foliar application of carbendazim. Plots having seed and soil application of T. harzianum and P. fluorescens alone had 11.5 per cent and 11.8 per cent disease severity, respectively. Observations recorded at the time of disease incidence revealed that combined application of $T$. harzianum and $P$. fluorescens delayed disease incidence by 35 days which was maximum among all the treatments. Seed and foliar application of carbendazim also delayed disease incidence by 27 days which was significantly lower than combined application of T. harzianum and P. fluorescens. Observations on plant growth parameters revealed that plant growth was maximum in plots having combined application of $T$. harzianum and $P$. fluorescens, in this treatment higher plant height $(112.0 \mathrm{~cm})$, shoot dry weight $(32.0 \mathrm{~g})$, root dry weight $(7.9 \mathrm{~g})$ were recorded. No significant increase in plant growth was recorded in plots receiving seed and foliar application of carbendazim. Studies on different treatments on yield attributes also established combined application of $T$. harzianum and $P$. fluorescens as the most effective treatment and resulted in 17.56 per cent increase in plant yield followed by T. harzianum (16.75\%) and P. fluorescens $(14.86 \%)$ alone, only 9.45 per cent increase in plant yield was recorded in plots having seed and foliar application of carbendazim.
\end{abstract}

HIND AGRICULTURAL RESEARCH AND TRAINING INSTITUTE 